Georgia State University

ScholarWorks @ Georgia State University

$3-5-2019$

\title{
Counteracting Climate Science Politicization With Effective Frames and Imagery
}

Toby Bolsen

Georgia State University, tbolsen@gsu.edu

Risa Palm

Georgia State University, risapalm@gsu.edu

Justin Kingsland

Georgia State University, jkingsland2@gsu.edu

Follow this and additional works at: https://scholarworks.gsu.edu/urban_studies_institute

Part of the Urban Studies and Planning Commons

\section{Recommended Citation}

Bolsen, Toby, Risa Palm, and Justin T. Kingsland. "Counteracting Climate Science Politicization With Effective Frames and Imagery." Science Communication 41, no. 2 (April 2019): 147-71. https://doi.org/ $10.1177 / 1075547019834565$.

This Article is brought to you for free and open access by the Urban Studies Institute at ScholarWorks @ Georgia State University. It has been accepted for inclusion in USI Publications by an authorized administrator of ScholarWorks @ Georgia State University. For more information, please contact scholarworks@gsu.edu. 


\title{
Counteracting Climate Science Politicization with Effective Frames and Imagery
}

\begin{abstract}
Politicization of science occurs when the inherent uncertainty of science is emphasized to cast doubt on scientific consensus. Climate change has become particularly susceptible to this kind of politicization. In this paper, we report the results of a survey experiment in which we manipulated text frames and visual imagery associated with two types of environmental hazards linked to climate change - sea level rise with associated flooding and increased heat levels with associated drought and wildfires. We present evidence that the use of visual imagery can counter the effects that science politicization has on climate change beliefs and behaviors.
\end{abstract}

Keywords: Framing, Climate Change, Science Politicization, Images

Citation: Bolsen, Toby, Risa Palm, and Justin Kingsland. 2019. "Counteracting Climate Science Politicization with Effective Frames and Imagery.” Science Communication 41(2): 147-170. https://journals.sagepub.com/doi/abs/10.1177/1075547019834565 
Initiatives informed by scientific findings can improve people's lives and generate knowledge that can be the basis for effective public policies. However, climate science in the United States has become politicized as a result of actors emphasizing the inherent uncertainty of science in an effort to cast doubt on the existence of a scientific consensus (Druckman, 2017; van der Linden et al., 2017). This politicization of science causes individuals to dismiss otherwise credible evidence and become uncertain about whether science can be trusted when invoked in political debates (Bolsen \& Druckman, 2015).

In general, public trust in science has declined in the United States among political conservatives (Gauchat, 2012; Hmielowski et al., 2014; Mooney, 2012), particularly for those aspects of science that could be considered as "impact science", including such issues as public health, the environment, and climate change (McCright et al., 2013). Conservatives' antipathy towards climate science in particular has manifested itself in both the legislative and the executive branches of the federal government on such topics as reduction in support of the Paris Agreement to limit carbon emissions, increased federal interest in increasing US coal production, and reductions in standards for energy efficiency (Selby, 2018).

Climate change is perhaps the paradigmatic example of how science politicization can sow doubt among the public over the veracity of scientific consensus messages (McCright \& Dunlap, 2011; Oreskes \& Conway, 2010) particularly in the United States (Bolsen, Druckman, \& Cook, 2015; Palm, Lewis, \& Feng, 2017). Given the urgency of this problem, and the increased isolation of the United States from the rest of the world community with respect to climate change policy, there is a pressing need to find ways to 
improve the effectiveness of communication about the scientific evidence for climate change and strategies to reduce the effects of science politicization.

A large literature explores how frames and strategic messages affect citizens' opinions and beliefs about various aspects of climate change (for reviews, see Bolsen \& Shapiro, 2017; Moser, 2010; O’Neill \& Smith, 2014). We build on existing research in three key ways: first, we evaluate how heretofore understudied frames in communication that emphasize sea level rise and coastal flooding or increased incidences of summer heat, drought and wildfires affect individuals' beliefs about climate change; second, we assess the impact of climate science politicization in competition with these distinct environmental impact frames given that few existing studies explicitly account for its presence when studying climate messaging efforts; and, third, we explore the efficacy of compelling visual imagery in conjunction with textual frames as a way to counter climate science politicization.

Data were collected in a large survey experiment conducted in May 2018. The experiment manipulated the presence of frames and images highlighting environmental hazards that are associated with climate change within the U.S.: sea level rise and coastal flooding of a major U.S. city (Boston), frames emphasizing climate change's effect on increased incidences of wildfires, droughts and heat waves, and the presence of climate science politicization. The results we report demonstrate that compelling frames affect citizens' beliefs and behaviors. In line with prior research, climate science politicization stunts credible textual frames. However, compelling imagery presented with the textual frames effectively counteracts science politicization and restores the impact of a consensus message. 


\section{Emphasis Framing Effects and Climate Change Beliefs}

Framing affects individuals' beliefs about various aspects of climate change. A frame consists of a word, phrase, or image that highlights a subset of the potentially relevant considerations toward any attitude object (e.g., candidate, issue, policy) (Druckman, 2001; Chong \& Druckman, 2007). ${ }^{1}$ For example, a message that makes the environmental impacts resulting from climate change more salient may cause greater relative emphasis on considerations about the environment when forming an overall risk assessment (Nisbet, 2009). ${ }^{2}$

Frames provided by journalists in media serve as narrative devices that help the public understand social problems, assign responsibility, and identify potential solutions (Entman, 1993; Gamson \& Modigliani, 1989). Experimental studies have tested the effect of strategically framed messages, for instance, relating the existence of a scientific consensus regarding human-made climate change, on beliefs and behaviors (Bolsen \& Druckman, 2018; Cook \& Lewandowsky, 2016; Deryungina \& Shurchkov, 2016;

Lewandowsky, Gignac, \& Vaughan, 2013; van der Linden et al., 2015). Lewandowsky et al. (2013) demonstrated that exposure to a frame highlighting the fact that $97 \%$ of climate

${ }^{1}$ This class framing effects is distinct from equivalency framing effects identified by Tversky and Kahneman (1981) in which information cast in a positive or negative light can lead to unconscious cognitive processing biases that shift opinions (Levin, Schneider, \& Gaeth, 1998; Druckman, 2004).

${ }^{2}$ When individuals are simultaneously exposed to competing emphasis frames of equal strength (i.e., directionally opposed frames toward the same attitude object) the effects of each individual frame may be cancelled out in competition (Chong and Druckman, 2007). 
scientists believe in human-caused climate change increases individuals' perception that a scientific consensus exists, acting as a gateway belief that influences other fundamental beliefs about climate change and increasing support for action (also see, van der Linden et al., 2014; van der Linden et al., 2016).

Prior research finds that many Americans view climate change as a low priority issue, and something that will mostly impact people in far away places in the distant future (Lorenzoni \& Pidgeon, 2006; Morton et al. 2011). One strategy scholars recommend to change this perception is to highlight the local and regional impacts that are already occurring as a result of climate change (Leiserowitz, 2007; Spence, Poortinga, \& Pidgeon, 2012). Along these lines, Bolsen, Kingsland, and Palm (2018) show that exposure to a frame accentuating sea level rise in one of two major U.S. cities as a result of polar ice melt caused individuals to increase perceptions that climate change will have a negative impact on U.S. coastal cities, express greater concern about the effects of climate change on communities in the U.S., and increase their belief that global warming is occurring. In another study, Scannell and Gifford (2013) found that frames emphasizing the local impact of climate change were more impactful on beliefs than frames that made salient its effects on distant locations (also see, Myers et al., 2012). We extend this literature by: (a) testing the impact of an understudied class of frames on climate beliefs; and, (b) accounting for the effects of rhetorical competition in the form of science politicization, a defining feature of climate debates in the U.S.

\section{Politicization of Science}

Existing scholarship makes clear that exposure to framed messages can shift beliefs about climate change, but largely fails to account for the politicization of science 
as a countervailing rhetorical force that may stunt otherwise effective frames. Science politicization involves more than simply the existence of conflict or debates among partisans on a given issue (Druckman, 2017). It occurs when an actor such as an elected official or interest group accentuates the inherent uncertainty of scientific evidence to cast doubt on the existence of a consensus, generating uncertainty and anxiety about whether science can be trusted when invoked in a politicized debate (Bolsen \& Druckman, 2015; Bolsen, Druckman, \& Cook, 2014).

U.S. media coverage of climate change has become increasingly connected with partisan politics since the issue gained public attention in the early 2000s. As a response to growing concern in the U.S. environmental community in the 1990s regarding the threat posed by human-induced climate change, "a coordinated anti-environmental countermovement, spearheaded by conservative think tanks, and politicians... sought to delegitimize global environmental problems, particularly anthropogenic global warming (McCright \& Dunlap, 2011, p. 158). The goal was to undermine support for regulatory policy action, in part by recruiting non-mainstream scientists to raise questions about the certainty of scientific consensus evidence (e.g., see McCright \& Dunlap, 2000; 2003; Oreskes \& Conway, 2011). McCright and Dunlap (2003) content analyzed hundreds of documents produced by conservative think tanks between 1990 and 1997, and found that climate skeptics often framed the scientific evidence supporting climate change as weak or non-existent.

Several studies have tested the process by which responsiveness to messages is affected by linking the message with partisan politics. McCright et al. (2016) conducted an experiment to test the effectiveness of exposure to one of four different emphasis 
frames that urged action on climate change: economic opportunity, national security, Christian stewardship, and public health. They found that any effect resulting from the frames disappeared in the presence of a counter-frame suggesting disagreement or the existence of scientific uncertainty. While two of the frames, economic opportunity and public health, increased participants beliefs about the positive effects of policies to combat climate change, the presence of a denial counter-frame eliminated this effect and significantly reduced respondents' beliefs in the reality of climate change, belief in the veracity of scientific information, and support for climate action. In another study, Bolsen and Druckman (2018) found that exposure to a message that highlighted scientific uncertainty and the role that politics plays in shaping how scientific evidence is reported undermined the positive effect of communicating consensus information about humaninduced climate change on low knowledge Democrats and Republicans. Similarly, Van der Linden et al. (2017) found that exposure to a message arguing that there is no scientific consensus on human-caused climate change decreased perceptions of scientific agreement and undermined the otherwise persuasive impact of a consensual scientific statement (also see, Cook, Lewandowsky \& Ecker, 2017). We extend this line of research by evaluating how science politicization in competition with framed messages highlighting the local environmental impacts of climate change affects risk perceptions.

Visual Imagery and Climate Beliefs

Science politicization may inhibit the effects of otherwise credible and impactful messages about climate change. However, compelling visual imagery along with textual frames reinforcing image content may be one way to counter this misleading rhetorical tactic. Visual information is known to be an effective means of communicating complex 
information and can improve information retention (Graber, 1990; Powell, Boomgaarden, De Swert, \& de Vreese, 2015). Clear and simple visual presentations of scientific evidence about climate change can shift the public's beliefs toward the scientific consensus (Leiserowitz, 2007; O’Neill, 2013; O’ Neill \& Smith, 2014; van der Linden, Leiserowitz, Feinberg, \& Maibach, 2014). Yet most of the research on framing effects in the domain of climate change has focused exclusively on how text rather than visual frames shape public opinion.

Several studies have explored how images associated with climate change affect individuals' related beliefs and actions (Hart, 2011; Hart \& Feldman, 2016; Leiserowitz, 2006; O'Neill et al., 2013; O’Neill \& Nicholson-Cole, 2009). For example, Hart and Feldman (2016) found that images of solar panels effectively increased perceptions of personal efficacy and indirectly promoted intentions to conserve energy as a way to fight climate change. Much of the prior research cataloguing dominant visual narratives in news stories about climate change in the U.S. demonstrates that the most common visual frames center around political conflict with pictures of individuals being most prominent, followed by geographically distant images of negative effects that will result from unchecked pollution (O'Neill, 2013; O’Neill et al., 2013). ${ }^{3}$ Visual imagery associated with climate change is also a feature of cable news stories on climate change (e.g., see Feldman et al., 2012), and outlets vary in the way in which they frame the issue, with

\footnotetext{
${ }^{3}$ O’Neill (2013) explains, “This ‘distancing' visual frame is exemplified through generic images of industrial smokestacks, ice imagery or non-human nature, rather than as an issue with impacts causes and solutions close to home" (p. 16).
} 
consequences for public understanding of climate science (Hmielowski, et al., 2014).

Imagery associated with climate change can influence beliefs about who is most vulnerable to its threats. For instance, iconic photographs of polar bears and melting glaciers that historically dominated media coverage's visual landscape may increase perceptions that it will mostly impact far away places in the distant future. Leiserowitz (2007) conducted a large nationally representative survey of Americans in late 2002 and early 2003 and asked them to name the first thought or image that came to mind when they heard the words "global warming." He identified 24 distinct thematic representations; however, two of the four most dominant mental images focused on melting ice and effects on non-human nature. Leiserowitz concluded that Americans "think the impacts [of climate change] will mostly affect people and places that are geographically distant" (2007, p. 8). One strategy recommended to more effectively engage audiences involves highlighting the "local" impacts that will result from climate change. Leiserowitz (2007) states that, "extreme events are vivid, dramatic, and easily understood," (p. 15), which provide re-occurring opportunities to educate audiences about the potential future impacts. ${ }^{4}$

Maps that highlight sea level rise and its effects on coastal communities in the U.S. may be an effective way to shift risk perceptions and beliefs. Retchless (2017) found that exposure to a map highlighting the local impacts of coastal flooding in Florida

\footnotetext{
${ }^{4}$ Leiserowitz further explains, "few Americans associate global warming with extreme events, such as heat waves, hurricanes, flood or drought, despite the fact that all are projected to increase in severity due to climate change" (p. 14).
} 
on college students shifted the risk perception of respondents who were initially doubtful or cautious about climate change, suggesting that using interactive maps showing sea level rise may be an effective "frame" for engaging skeptical audiences. ${ }^{5}$

Images presented in conjunction with text frames often produce stronger framing effects (Feldman \& Hart, 2018; Graber, 1996; Powell et al., 2015), but prior research in this area has not accounted for climate science politicization as a rhetorical counterforce that may undermine effective framing strategies. Further, few studies manipulate both text and visual content simultaneously and no studies, to our knowledge, have explored whether visual imagery appearing alongside congruent text frames can combat the politicization of climate science and resuscitate the impact of credible and otherwise persuasive scientific information.

Based on the extant literature on emphasis framing effects, climate science politicization, and the power of visual imagery, we posit three hypotheses that we tested in the study we describe in detail below:

1. Text emphasizing the effects of sea level rise or increased temperatures resulting from climate change will increase individuals' perceptions that climate change is happening and important, and that it will have negative effects. Text emphasizing temperature rise, drought and wildfires as opposed to sea level rise will also increase perceptions that climate change is affecting daily weather.

\footnotetext{
${ }^{5}$ Retchless (2017) states, “Although interactive sea level rise maps are one of the more popular means of depicting detailed and local sea level rise impacts, their potential for engaging audiences remains largely unevaluated"(p.6).
} 
2. Climate science politicization will reduce or cancel out any effects resulting from exposure to the framed messages.

3. Visual imagery in conjunction with textual frames will counteract the effect that results from exposure to counter-frames (i.e., climate science politicization) and restore the impact of the textual frames.

Van der Linden (2017) has also called for research that predicts actual behavior: "much less is known about how and in what ways people's concern about climate change drives them to adopt specific behaviors ... future research would benefit from becoming more decision-focused" (p. 28). ${ }^{6}$ Given the dearth of research that evaluates how frames regarding climate change alone or in competition with counter-frames designed to generate uncertainty about scientific consensus messages affect behavioral engagement measures (but see Levine \& Kline, 2017; Ockwell, Whitmarsh \& O’Neill, 2009), we also report how the information we provided to respondents affected their expressed interest in learning more about climate change and willingness to pay additional taxes to fight climate change.

\footnotetext{
${ }^{6}$ Levine and Kline (2017) argue that, "optimal frames would both increase stated support for climate-friendly policies and also increase people's willingness to spend scarce resources of time, money, and attention communicating that support” (p. 302). This literature demonstrates the importance of assessing not only how framed information impacts opinions but also assessing its effects on behavioral measures of engagement on climate change (also see, Brody et al., 2012; Lubell, Zahran, \& Vedlitz, 2007; Zahran et al., 2006).
} 


\section{Data and methodology}

Our survey of 1986 unique respondents recruited using Amazon’s Mechanical Turk (MTurk) was conducted in May 2018. MTurk is a widely used online crowdsourcing platform that generates more diverse samples that many randomized experiments that rely on undergraduate students (Berinsky et al., 2012; Paolacci et al., 2010). As with other convenience samples, MTurk differs in several ways from a general population sample (but not in ways that impede making generalizable causal inferences, see Levay, Freese, \& Druckman, 2016); for instance, participants tend to be more educated and express higher levels of political interest. Nonetheless, it is commonly used in the social sciences to estimate causal relationships, and the results are comparable to identical studies fielded on general population samples (Mullinix et al., 2015). ${ }^{7}$

Each participant was randomly assigned to a pure control condition, or to one of eight treatment conditions: (1) text frame that sea levels will rise according to the Fourth National Climate Assessment, increasing the frequency and severity of flooding along the Atlantic and Gulf coasts; (2) text frame that wildfires and droughts will increase in parts

\footnotetext{
${ }^{7}$ The MTurk sample we collected was large and diverse. In our sample, $26 \%$ of respondents identify as Republican, $26 \%$ identify as Independent, and $48 \%$ identify as Democrat. Recent polling from Gallup from October $1^{\text {st }}-10^{\text {th }}, 2018$ shows $28 \%$ of respondents identify as Republican, 39\% as Independent, and 30\% as Democrat. On racial representativeness, $76 \%$ of respondents in our sample identify as white, $8 \%$ African American, 7\% Asian American, and 5\% Hispanic. Further, our sample is 49\% female and $51 \%$ male. Other descriptive statistics for the sample are available upon request from the corresponding author.
} 
of the West and South as a consequence of rising global temperatures according to the Fourth Climate Assessment; (3) an animated map in conjunction with the text frame that highlights the amount of sea level rise projected to occur with a $3.5 \mathrm{~F}(2.0 \mathrm{C})$ increase in Earth's average temperature in Boston; (4) an animated map in conjunction with the text frame that highlights increased incidences of heat waves, wildfires, and droughts illustrating the projected number of days over 100 degrees Fahrenheit across the continental U.S. over time. In addition, (conditions 5-8) each of the above stimuli was coupled with a counter-frame that politicized the consensus information by highlighting scientific uncertainty and the role that politics plays in the selective reporting of evidence to advocate for favored policies.

Participants in all conditions were informed at the beginning of the survey that they would be asked some questions about their opinions on the issue of climate change. Individuals randomly assigned to the control condition immediately proceeded to answer the key dependent variables presented below. Participants in all other conditions read a short article prior to responding to the dependent measures. Each stimulus included a headline, for instance, "Report Highlights Sea Level Rise and Frequent Flooding in Parts of the U.S.," followed by several sentences of related text highlighting the particular frame associated with each condition. The text of the sea level rise and coastal flooding stimuli, for example, stated that polar ice is melting because of rising global temperatures, and that the report indicates "flooding will increase in frequency and severity along the Atlantic and Gulf coasts [and] change the landscape of coastal communities and make them less livable." The text for the conditions highlighting increased heat waves, droughts and wildfires focused on how such events have increased 
as a result of rising global temperatures, and that the report predicts "that wildfires and droughts will increase in frequency and severity in parts of the West and South [and] change the landscape of these areas and make them less livable."

For the conditions in which science politicization was introduced, the headline included the word "Debated [Report]" and several additional sentences designed to cast doubt on the consensual scientific information. Similar to other experimental research that has employed such claims, we designed the stimuli to emphasize uncertainty about the information in the report by stating, "... the issue of climate change has been a point of intense political debate. Some say politics make it difficult to assess future changes that will occur as a result of climate change. There is simply too much uncertainty. People use science selectively to advocate for favored policies. This may be true even for the recent National Climate Assessment report." This operationalization is consistent with that employed in existing research on science politicization (e.g., Bolsen et al., 2014, Bolsen \& Druckman, 2015; McCright et al., 2016; van der Linden et al., 2017).

Climate change is likely to have two primary impacts on the United States over the next decades: those related to sea level rise and coastal flooding, and those related to increased temperatures including heat waves, drought, wildfires and intense precipitation (Wuebbles, Fahey, \& Hibbard, 2017). These impacts were portrayed in our study design within two environmental settings. We illustrated the impacts of sea level rise with the example of coastal flooding that will occur in Boston as a result of a 15 foot increase in the sea level associated with an increase in the Earth's temperature of 3.5 degrees Fahrenheit. We had pretested a similar stimulus using sea level rise in Miami, and found that the Boston example elicited a clearer response. We created the animated map using 
flood projection images produced by Climate Central's "Surging Seas: Seeing Choices". ${ }^{8}$ The second environmental condition we tested was increased heat with associated drought and wildfires since weather-related events linked to climate change have received increasing news attention. Moreover, climate change is often thought of interchangeably with global "warming" and strongly associated with heat related imagery (Leiserowitz, 2006; Schuldt \& Roh, 2014). Some participants were randomly assigned to a condition that included a different animated map showing the number of days over 100 degrees Fahrenheit over time (i.e., 1990-2010; by 2050; and by 2100) produced by Climate Central. ${ }^{9}$ Figure 1 displays the images that we combined to create the animated visual treatments. The screenshots were merged into a moving image that cycled through the progression of the projected sea level rise and heat-maps, respectively.

[Insert Figure 1 about here]

We measured how exposure to the treatments affected individuals' beliefs about: (1) whether climate change is happening (1-7 scale, definitely not happening to definitely happening); (2) whether climate change will have negative / positive impacts on the U.S. (1-7 scale, extremely negative to extremely positive); (3) personal importance of climate change (1-5 scale, extremely unimportant to extremely important); (4) how much climate change is affecting weather in the U.S. ( $1=$ not at all; $5=$ a great deal $) ;(5)$ interest in learning more about the possible effects of climate change in the U.S. (1-7 scale, extremely uninterested to extremely interested); and, (6) willingness to pay more in

\footnotetext{
${ }^{8}$ The images are available at: http://sealevel.climatecentral.org/maps

${ }^{9}$ The images are available at: http://www.climatecentral.org/gallery/maps/days-above100f-projections
} 
yearly taxes so that the U.S. government can prepare to fight climate change $(\$ 0-\$ 500$ range). Table 1 displays the stimuli for each condition and the corresponding hypothesis we test.

\section{[Insert Table 1 here]}

\section{Results}

We evaluate the impact of the experimental conditions on belief that climate change is happening, perceived negative impacts, and personal importance by regressing each dependent variable on the experimental conditions, omitting the control condition as the baseline in all reported analyses. We include covariates for party identification and level of education in estimating treatment effects for both theoretical and empirical reasons. First, party identification and education are both known and theoretically meaningful predictors of climate attitudes (Hamilton, 2011; Kahan, 2015: Kahan et al., 2012), and thus relevant for inclusion, and second, there were random imbalances for both across our experimental conditions. We expect the inclusion of these covariates to explain a meaningful amount of variance in our dependent variables as is consistent with prior research, as well as increase the efficiency of our analyses in light of slight imbalances in assignment across our treatment groups. ${ }^{10}$

\footnotetext{
${ }^{10}$ We conducted additional analyses in which we estimated treatment effects without the inclusion of education and party identification. The substantive interpretation of the results is the same; however, model efficiency improves with the inclusion of the additional covariates where we detected imbalances post-randomization. All supplemental files and analyses are available upon request from the authors.
} 
The first column in Table 2 reports the impact of the experimental conditions on belief that climate change is happening (Model 1). First, in support of Hypothesis 1, the text frame emphasizing coastal flooding that will occur in the Atlantic and Gulf coasts as a result of sea level rise significantly increases individuals' belief that climate change is happening relative to the control condition $(p=.05)$; this effect is slightly larger when the text frame appears in conjunction with the animated map showing inundation of Boston $(p=.03) .{ }^{11}$ Also in support of Hypothesis 1, Model 1 reports that the text frame emphasizing increased incidences of drought, heat waves, and wildfires significantly increased respondents' belief that climate change is happening relative to the baseline ( $p$ $=.02$ ); this emphasis framing effect also strengthens when the animated map highlighting temperature increases in the U.S. over time appears alongside the text frames $(p<.01)$.

The results reported in Table 2 (Model 2) also provide support for Hypothesis 1, as the text frame highlighting sea level rise and coastal flooding significantly increased perceptions that climate change will have negative impacts $(p=.06)$, and this effect strengthens when the text frame appears alongside the animated map $(p=.01)$. Similarly, the text frame highlighting an increased incidence of droughts, wildfires, and heat waves significantly increased perceptions that climate change will have negative impacts $(p<$ $.01)$; this effect also strengthens when the animated map is included with the text frame $(p<.01)$

\footnotetext{
${ }^{11}$ The substantive movement on the response scales due to the experimental conditions can be easily interpreted as it roughly reflects the size of the regression coefficient in each model.
} 
However, when we looked at the effects of the treatment on whether or not the respondents viewed climate change as an important issue, we found different results. The text frame alone highlighting sea level rise did not increase perceived personal importance of climate change (Table 2, Model 3); however, when the frame was coupled with the animated map showing inundation of Boston, respondents reported significantly higher levels of the issue's personal importance $(p=.09)$. The text frame emphasizing increased incidences of drought and heat waves, in support of Hypothesis 1, significantly increased the perceived importance of the issue $(p=.01)$, and this effect persisted when the frame was coupled with the animated map showing temperature increases in the U.S. over time $(p=.06)$.

Model 1 in Table 2 also reports evidence in support of Hypothesis 2 and Hypothesis 3. Exposure to counter-frames that highlight scientific uncertainty and the role of politics in shaping news the issue, in support of Hypothesis 2, undermines the positive effect of the flood and drought text's impact on belief climate change is happening. The effectiveness of each text frame is restored, however, in support of Hypothesis 3, when either text frame appears with an additional animated map, (Flood + Politicization + Map, $p=.05$; Drought + Politicization + Map, $p=.01)$. Similarly, the positive impact of the text drought frame on perceptions about the personal importance of climate change vanished in the presence of counter-frames that emphasized scientific uncertainty (Model 3, Table 2), but the effect of the scientific consensus information was restored when it was presented with the animated map. The results suggest that effective visual frames in conjunction with congruent text frames can counter the negative effects that result from efforts to undermine scientific consensus information about climate 
change. Note that counter to Hypothesis 2 science politicization did not cancel out the impact that the text frames had on increasing respondents' perceptions about the negative impacts that would occur as a result of climate change (Table 2, Model 2).

Although not the focus of this paper, the results reported in each model confirm the expected relationships between party affiliation and climate beliefs. Republicans (Democrats) are significantly less likely (more likely) than Independents (i.e., the omitted reference group in each model) to say that climate change is happening, that it will have negative effects, and to attach personal importance to the issue. Higher levels of education are also associated with increased belief that climate change is happening and greater personal importance.

\section{[Insert Table 2 here]}

Hypothesis 1 stated that exposure to a frame highlighting the increased frequency and severity of environmental natural hazards such as heat waves, droughts and wildfires would shift respondents' perceptions about the extent to which climate change affects daily weather. The first column of results in Table 3 (Model 1) confirms this prediction. Exposure to the drought frame with or without the animated map significantly increased respondents' belief that climate change is having an effect on daily weather $(p=.01)$. Consistent with Hypothesis 2, the positive effect of the textual frame in isolation disappears in the presence of a counter-frame introducing doubt. However when the frame is reinforced by the presence of an animated map showing increased incidences of heat waves across the continental U.S. over time, in support of Hypothesis 3 climate science politicization's effect is vitiated.

[Insert Table 3 here] 
To evaluate the degree to which the frames we employ shape not only beliefs but also behaviors, we regressed respondents' interest in learning more about the effects of climate change in the U.S. on the experimental conditions. The results are reported in Table 3 (Model 2). First, we observe that drought text by itself or coupled with the animated map showing increased incidences of heat waves significantly increased respondents' interest in learning more about climate change's effects $(p=.01)$. The counter-frame introducing doubt eliminates the frame's effect and the animated map does not vitiate this effect. The coastal flooding text frame presented in isolation had no effect on respondents' interest in learning more about climate change (Model 2). However, when the frame was presented with an animated map showing inundation of Boston, interest in learning more about climate change's impacts on the U.S. increases significantly $(p=.03)$, and this effect persists in the presence of the counter-frame ( $p=$ $.05)$.

We also asked respondents to enter the maximum amount they would be willing to pay in additional taxes so that the U.S. government can prepare for climate change. The results, reported in Table 3 (Model 3), are similar to what we find for informationseeking behavior. First, the drought frame presented with or without the animated map significantly increases individuals' reported willingness to pay additional yearly taxes to combat climate change ( $p=.01$ and $p=.08$, respectively). The counter-frame eliminates the frame's effect and the map in conjunction with the text frame does not restore its impact. The textual frame highlighting coastal flooding does not have any effect on willingness to pay additional yearly taxes, but the animated map coupled with the textual frame significantly increases the reported amount people will contribute $(p=.07)$. A 
counter-frame eliminates the effect of the animated flood map with the textual frame on willingness to pay more in additional taxes similar to its effect on behavior in the drought frame conditions. The results reported in each model in Table 3 confirm the expected relationships between party affiliation and climate beliefs. Republicans (Democrats) are significantly less likely (more likely) than Independents (i.e., the omitted reference group in each model) to say that climate change is affecting weather, want to learn more about climate change's effects, or be willing to pay additional taxes to help reduce its impacts. Higher levels of education are also associated with increased interest in learning more about the effects of climate change and a greater willingness to pay more in taxes to combat its effects.

\section{Discussion}

Major questions remain that need to be explored in future research. First, although we recruited a large and diverse sample, it is not geographically representative enough to study questions regarding how living in areas that experience regular coastal flooding or extreme weather moderate the impact of the frames we employ, or how such factors may condition efforts to counteract climate science politicization. Existing scholarship suggests that geographic factors may play a crucial role in how targeted audiences respond to strategic communications about climate change's environmental effects (Howe et al., 2015; Zahran et al., 2006; Zhang et al., 2018). This is clearly an important area for future work.

Second, we also acknowledge that a host of individual-level factors may condition the impact of the frames and images within our experimental conditions, such as party identification, cultural worldviews, values, personality traits such as open-mindedness, 
and other demographic characteristics. A growing literature demonstrates that motivated reasoning plays a powerful role in shaping how citizens in the U.S. approach, process and evaluate strategic messages regarding climate change (Kahan, 2015; Kahan et al., 2012). In the real world, climate skeptics may seek out information that supports their existing beliefs or worldviews, avoid or dismiss information that challenges their opinions, and view evidence and arguments that reinforce their existing views as stronger - increasing polarization in the face of scientific communication efforts. These processes are especially important to account for given the rise of social media and the ability of individuals who share similar views about climate change to interact with each other in homogenous discussion networks, creating "echo chambers" and further entrenching climate polarization (Hart, Feldman, Leiserowitz, \& Maibach, 2015; Feldman, Myers, Hmielowski, \& Leiserowitz, 2014). This is beyond the scope of the present study, but future work should continue to document how such factors can moderate targeted climate science communications.

Third, additional work is also needed to understand how climate science politicization and frames emanating from different sources (e.g., party leaders, military officials, advocacy groups, etc.) affect receptiveness to such messages (Lupia, 2013; Druckman, 2015). Given existing levels of partisan and ideological polarization on the issue of climate change in the U.S., and the increased likelihood of motivated reasoning in polarized political contexts, information that emanates from in-group sources may be much more effective than the same information provided from an out-group member. Yet few studies to date explore how varying the source of arguments or scientific 
information associated with climate change affects different audiences in the U.S. This is an area for future research.

Fourth, as in all experimental research, it will be important to translate these findings to practices that could increase the effectiveness of climate change information. At present, several private non-profit organizations have taken steps to provide prospective home-buyers and general citizens with very detailed and systematic visual portrayals of the likely impacts of sea level rise associated with climate change. Two examples are Climate Central, the authors of the "surging seas" automated maps that were used in this study to illustrate the effects of sea level rise in Boston, funded by numerous donors including the Schmidt family foundation, the Kresge Foundation, the Rockefeller foundation and others (http://sealevel.climatecentral.org/about/funding), and the First Street Foundation, developer of a website whose goal is to provide information concerning tidal flooding and hurricane storm surge to home owner and home buyers (https://medium.com/firststreet/from-forprofit-to-nonprofit-eb8d1c4a9e16). The impact that this type of localized and specific information has on dampening politicization of climate change science will need to be explored.

\section{Conclusion}

The public's perceptions of the risks presented by climate change and the steps they are willing to take to support adaptation or mitigation efforts are a crucial component of the socio-political context that can constrain or compel policy makers to address the issue (Leiserowitz, 2007; Campbell \& Kay, 2014). The ability of science to elevate public discourse on climate change, however, requires effective communication strategies (Druckman \& Lupia, 2017; National Academy of Sciences, 2017). The 
politicization of climate science by actors seeking to sow doubt among the public has resulted in distrust among large segments of the US public, particularly conservatives and Republicans, resulting in polarization and stunted support for policy action (Druckman, 2013). This paper highlights a promising communication strategy that may help combat climate science politicization.

The finding that compelling images that reinforce effective textual frames weaken climate science politicization is one that should prompt further exploration. As the communication intended to persuade audiences concerning everything from purchase decisions to political perspectives evolves from more traditional media to the use of personalized, social media and the use of visual imagery, it will be even more important to chart the ways in which non-traditional formats can be used effectively. 


\section{References}

Berinsky, A. J., Huber, G. A., \& Lenz, G. S. (2012). Evaluating online labor markets for experimental research: Amazon. com's Mechanical Turk. Political Analysis, 20(3), 351-368.

Bolsen, T., \& Druckman, J. N. (2018). Do partisanship and politicization undermine the impact of a scientific consensus message about climate change?. Group Processes \& Intergroup Relations, 21(3), 389-402.

Bolsen, T., \& Druckman, J. N. (2015). Counteracting the politicization of science. Journal of Communication, 65(5), 745-769.

Bolsen, T., Druckman, J. N., \& Cook, F. L. (2015). Citizens', scientists', and policy advisors' beliefs about global warming. The ANNALS of the American Academy of Political and Social Science, 658(1), 271-295.

Bolsen, T., Druckman, J. N., \& Cook, F. L. (2014). How frames can undermine support for scientific adaptations: Politicization and the status-quo bias. Public Opinion Quarterly, 78(1), 1-26.

Bolsen, T., Kingsland, J., \& Palm, R. (2018). The impact of frames highlighting coastal flooding in the USA on climate change beliefs. Climatic Change, 147(1-2), 359368.

Bolsen, T., Leeper, T. J., \& Shapiro, M. A. (2014). Doing what others do: Norms, science, and collective action on global warming. American Politics Research, 42(1), 65-89.

Bolsen, T., \& Shapiro, M. A. (2018). The US news media, polarization on climate change, and pathways to effective communication. Environmental Communication, 12(2), 149-163.

Bolsen, T., \& Shapiro, M.A. (2017). Strategic framing and persuasive messaging to influence climate change perceptions and decisions. Oxford Research Encyclopedia of Climate Science.

Brody, S. D., Zahran, S., Vedlitz, A., \& Grover, H. (2008). Examining the relationship between physical vulnerability and public perceptions of global climate change in the United States. Environment and Behavior, 40(1), 72-95.

Brody, S., Grover, H., \& Vedlitz, A. (2012). Examining the willingness of Americans to alter behaviour to mitigate climate change. Climate Policy, 12(1), 1-22. 
Campbell, T. H., \& Kay, A. C. (2014). Solution aversion: On the relation between ideology and motivated disbelief. Journal of Personality and Social Psychology, 107(5), 809.

Chong, D., \& Druckman, J. N. (2007). Framing theory. Annual Review of Political Science, 10, 103-126.

Cook, J., Lewandowsky, S., \& Ecker, U. K. (2017). Neutralizing misinformation through inoculation: Exposing misleading argumentation techniques reduces their influence. PloS one, 12(5), e0175799.

Cook, J., \& Lewandowsky, S. (2016). Rational irrationality: Modeling climate change belief polarization using Bayesian networks. Topics in Cognitive Science, 8(1), 160-179.

Deryugina, T., \& Shurchkov, O. (2016). The effect of information provision on public consensus about climate change. PloS one, 11(4), e0151469.

Druckman, J. N. (2001). The implications of framing effects for citizen competence. Political Behavior, 23(3), 225-256.

Druckman, J. N. (2004). Political preference formation: Competition, deliberation, and the (ir) relevance of framing effects. American Political Science Review, 98(4), 671-686.

Druckman, J. N. (2015). Communicating policy-relevant science. PS: Political Science \& Politics, 48(S1), 58-69.

Druckman, J. N. (2013). Public opinion: Stunted policy support. Nature Climate Change, 3(7), 617.

Druckman, J. N. (2017). The crisis of politicization within and beyond science. Nature Human Behaviour, 1(9), 615.

Druckman, J. N., \& Lupia, A. (2017). Using frames to make scientific communication effective. In D. Scheufele, D.M. Kahan, K.H. Jamieson, (Eds.), Handbook of the Science of Science Communication (pp. 13-31). New York, NY: Oxford University Press.

Entman, R. M. (1993). Framing: Toward clarification of a fractured paradigm. Journal of Communication, 43(4), 51-58.

Feldman, L., \& Hart, P.S. (2018). Is there any hope? How climate change news imagery and text influence audience emotions and support for climate mitigation policies. Risk Analysis, 38(3), 585-602. 
Feldman, L., Maibach, E. W., Roser-Renouf, C., \& Leiserowitz, A. (2012). Climate on cable: The nature and impact of global warming coverage on Fox News, CNN, and MSNBC. The International Journal of Press/Politics, 17(1), 3-31.

Feldman, L., Myers, T. A., Hmielowski, J. D., \& Leiserowitz, A. (2014). The mutual reinforcement of media selectivity and effects: Testing the reinforcing spirals framework in the context of global warming. Journal of Communication, 64(4), $590-611$.

Gamson, W. A., \& Modigliani, A. (1989). Media discourse and public opinion on nuclear power: A constructionist approach. American Journal of Sociology, 95(1), 1-37.

Gauchat, G. (2012). Politicization of science in the public sphere: A study of public trust in the United States, 1974 to 2010. American Sociological Review, 77(2), $167-187$.

Graber, D. A. (1990). Seeing is remembering: How visuals contribute to learning from television news. Journal of Communication, 40(3), 134-156.

Graber, D. A. (1996). Say it with pictures. The Annals of the American Academy of Political and Social Science, 546(1), 85-96.

Hamilton, L. C. (2011). Education, politics and opinions about climate change evidence for interaction effects. Climatic Change, 104(2), 231-242.

Hart, P. S. (2011). One or many? The influence of episodic and thematic climate change frames on policy preferences and individual behavior change. Science Communication, 33(1), 28-51.

Hart, P. S., \& Feldman, L. (2016). The impact of climate change-related imagery and text on public opinion and behavior change. Science Communication, 38(4), 415441.

Hart, P. S., \& Feldman, L. (2014). Threat without efficacy? Climate change on US network news. Science Communication, 36(3), 325-351.

Hart, P. S., Feldman, L., Leiserowitz, A., \& Maibach, E. (2015). Extending the impacts of hostile media perceptions: influences on discussion and opinion polarization in context of climate change. Science Communication, 37(4), 506-532.

Hmielowski, J. D., Feldman, L., Myers, T. A., Leiserowitz, A., \& Maibach, E. (2014). An attack on science? Media use, trust in scientists, and perceptions of global warming. Public Understanding of Science, 23(7), 866-883. 
Howe, P. D., Mildenberger, M., Marlon, J. R., \& Leiserowitz, A. (2015). Geographic variation in opinions on climate change at state and local scales in the USA. Nature Climate Change, 5(6), 596.

Kahan, D. M. (2015). Climate-science communication and the measurement problem. Political Psychology, 36, 1-43.

Kahan, D. M., Peters, E., Wittlin, M., Slovic, P., Ouellette, L. L., Braman, D., \& Mandel, G. (2012). The polarizing impact of science literacy and numeracy on perceived climate change risks. Nature Climate Change, 2(10), 732.

Leiserowitz, A. A. (2005). American risk perceptions: Is climate change dangerous?. Risk Analysis, 25(6), 1433-1442.

Leiserowitz, A. (2006). Climate change risk perception and policy preferences: The role of affect, imagery, and values. Climatic change, 77(1-2), 45-72.

Leiserowitz, A. (2007). Communicating the risks of global warming: American risk perceptions, affective images, and interpretive communities. In S.C. Moser, L. Dilling (Eds.), Creating a climate for change: Communicating Climate Change and Facilitating Social Change, (pp. 44-63). Cambridge: Cambridge University Press.

Levay, K. E., Freese, J., \& Druckman, J. N. (2016). The demographic and political composition of Mechanical Turk samples. Sage Open, 6(1), 2158244016636433.

Levin, I. P., Schneider, S. L., \& Gaeth, G. J. (1998). All frames are not created equal: A typology and critical analysis of framing effects. Organizational Behavior and Human Decision Processes, 76(2), 149-188.

Levine, A. S., \& Kline, R. (2017). A new approach for evaluating climate change communication. Climatic Change, 142(1-2), 301-309.

Lewandowsky, S., Gignac, G. E., \& Vaughan, S. (2013). The pivotal role of perceived scientific consensus in acceptance of science. Nature Climate Change, 3(4), 399.

Lorenzoni, I., \& Pidgeon, N. F. (2006). Public views on climate change: European and USA perspectives. Climatic Change, 77(1-2), 73-95.

Lubell, M., Zahran, S., \& Vedlitz, A. (2007). Collective action and citizen responses to global warming. Political Behavior, 29(3), 391-413.

Lupia, A. (2013). Communicating science in politicized environments. Proceedings of the National Academy of Sciences, 110(Supplement 3), 14048-14054. 
McCright, A. M., Charters, M., Dentzman, K., \& Dietz, T. (2016). Examining the effectiveness of climate change frames in the face of a climate change denial counter-Frame. Topics in Cognitive Science, 8(1), 76-97.

McCright, A. M., \& Dunlap, R. E. (2000). Challenging global warming as a social problem: An analysis of the conservative movement's counter-claims. Social Problems, 47(4), 499-522.

McCright, A. M., \& Dunlap, R. E. (2003). Defeating Kyoto: The conservative movement's impact on US climate change policy. Social Problems, 50(3), 348373.

McCright, A. M., Dentzman, K., Charters, M., \& Dietz, T. (2013). The influence of political ideology on trust in science. Environmental Research Letters. 8:044029. doi:10.1088/1748-9326/8/4/04402

McCright, A. M., \& Dunlap, R. E. (2011). The politicization of climate change and polarization in the American public's views of global warming, 2001-2010. The Sociological Quarterly, 52(2), 155-194.

Mooney, C. (2012). The Republican Brain: The Science of Why They Deny Science--and Reality. Hobokon, NJ: John Wiley \& Sons.

Morton, T. A., Rabinovich, A., Marshall, D., \& Bretschneider, P. (2011). The future that may (or may not) come: How framing changes responses to uncertainty in climate change communications. Global Environmental Change, 21(1), 103-109.

Moser, S. C. (2010). Communicating climate change: History, challenges, process and future directions. Wiley Interdisciplinary Reviews: Climate Change, 1(1), 31-53.

Mullinix, K. J., Leeper, T. J., Druckman, J. N., \& Freese, J. (2015). The generalizability of survey experiments. Journal of Experimental Political Science, 2(2), 109-138.

Myers, T. A., Nisbet, M. C., Maibach, E. W., \& Leiserowitz, A. A. (2012). A public health frame arouses hopeful emotions about climate change. Climatic Change, 113(3-4), 1105-1112.

National Academies of Sciences, Engineering, and Medicine. (2017). Communicating Science Effectively: A Research Agenda. Washington, DC: The National Academies Press.

Nisbet, M. C. (2009). Communicating climate change: Why frames matter for public engagement. Environment: Science and Policy for Sustainable Development, 51(2), 12-23. 
Ockwell, D., Whitmarsh, L., \& O'Neill, S. (2009). Reorienting climate change communication for effective mitigation: Forcing people to be green or fostering grass-roots engagement?. Science Communication, 30(3), 305-327.

O’Neill, S. J. (2013). Image matters: Climate change imagery in US, UK and Australian newspapers. Geoforum, 49, 10-19.

O’Neill, S. J., Boykoff, M., Niemeyer, S., \& Day, S. A. (2013). On the use of imagery for climate change engagement. Global Environmental Change, 23(2), 413-421.

O'Neill, S., \& Nicholson-Cole, S. (2009). "Fear won't do it": Promoting positive engagement with climate change through visual and iconic representations. Science Communication, 30(3), 355-379.

O'Neill, S. J., \& Smith, N. (2014). Climate change and visual imagery. Wiley Interdisciplinary Reviews: Climate Change, 5(1), 73-87.

Oreskes, N., \& Conway, E. M. (2011). Merchants of Doubt: How a Handful of Scientists Obscured the Truth on Issues from Tobacco Smoke to Global Warming. New York, NY: Bloomsbury Publishing USA.

Palm, R., Lewis, G. B., \& Feng, B. (2017). What causes people to change their opinion about climate change?. Annals of the American Association of Geographers, 107(4), 883-896.

Paolacci, G., Chandler, J., \& Ipeirotis, P.G. (2010). Running experiments on Amazon Mechanical Turk. Judgment and Decision Making, 5(August): 411-9.

Powell, T. E., Boomgaarden, H. G., De Swert, K., \& de Vreese, C. H. (2015). A clearer picture: The contribution of visuals and text to framing effects. Journal of Communication, 65(6), 997-1017.

Retchless, D.P. (2017). Understanding local sea level rise risk perceptions and the power of maps to change them: The effects of distance and doubt. Environmental Behavior, 1-29.

Scannell, L., \& Gifford, R. (2013). Personally relevant climate change: The role of place attachment and local versus global message framing in engagement. Environment and Behavior, 45(1), 60-85.

Schuldt, J. P., \& Roh, S. (2014). Of accessibility and applicability: How heat-related cues affect belief in "global warming" versus "climate change." Social Cognition, 32(3), 217-238. 
Selby, J. (2018). The Trump presidency, climate change, and the prospect of a disorderly energy transition." Review of International Studies https://doi.org/10.1017/S0260210518000165 Published online: 09 October 2018

Spence, A., Poortinga, W., \& Pidgeon, N. (2012). The psychological distance of climate change. Risk Analysis, 32(6), 957-972.

Tversky, A., \& Kahneman, D. (1981). The framing of decisions and the psychology of choice. Science, 211(4481), 453-458.

van der Linden, S. (2017). Determinants and measurement of climate change risk perception, worry, and concern. In M. Nisbet (Ed.) Oxford Research Encyclopedia of Climate Science. Oxford: Oxford University Press.

van der Linden, S. L., Leiserowitz, A. A., Feinberg, G. D., \& Maibach, E. W. (2014). How to communicate the scientific consensus on climate change: Plain facts, pie charts or metaphors?. Climatic Change, 126(1-2), 255-262.

van der Linden, S., Leiserowitz, A., Rosenthal, S., \& Maibach, E. (2017). Inoculating the public against misinformation about climate change. Global Challenges, 1(2), 17.

Wuebbles, D., D. W. Fahey, and K. A. Hibbard (2017), How will climate change affect the United States in decades to come?. Eos, 98.

Zahran, S., Brody, S. D., Grover, H., \& Vedlitz, A. (2006). Climate change vulnerability and policy support. Society and Natural Resources, 19(9), 771-789.

Zhang, B., van der Linden, S., Mildenberger, M., Marlon, J. R., Howe, P. D., \& Leiserowitz, A. (2018). Experimental effects of climate messages vary geographically. Nature Climate Change, 8(5), 370. 
Table 1. Experimental Design and Predictions

\begin{tabular}{|c|c|c|}
\hline No Politicization & Description / N & Hypotheses / Research Questions \\
\hline No Frame (Control) & Baseline $(N=218)$ & N/A \\
\hline Coastal Flooding Frame & $\begin{array}{l}\text { Textual frame only } \\
(N=221)\end{array}$ & $\begin{array}{l}\text { 个 happening / impacts / } \\
\text { importance / info-seeking / WTP } \\
\text { tax }\end{array}$ \\
\hline Extreme Weather Frame & $\begin{array}{l}\text { Textual frame only } \\
(N=221)\end{array}$ & $\begin{array}{l}\text { 个 happening / impacts / } \\
\text { importance / info-seeking / WTP } \\
\text { tax / *weather }\end{array}$ \\
\hline $\begin{array}{l}\text { Coastal Flooding + } \\
\text { Image (Boston) }\end{array}$ & $\begin{array}{l}\text { Text + Animated Map } \\
(N=221)\end{array}$ & $\begin{array}{l}\text { 个 happening / impacts / } \\
\text { importance / info-seeking / WTP } \\
\text { tax }\end{array}$ \\
\hline $\begin{array}{l}\text { Extreme Weather Frame } \\
+ \text { Image (Heat Map) }\end{array}$ & $\begin{array}{l}\text { Text + Animated Map } \\
(N=222)\end{array}$ & $\begin{array}{l}\text { 个 happening / impacts / } \\
\text { importance / info-seeking / WTP } \\
\text { tax / *weather }\end{array}$ \\
\hline \multicolumn{3}{|l|}{ Politicization Present } \\
\hline Coastal Flooding Frame & $\begin{array}{l}\text { Competing text frames } \\
\text { only } \\
(N=220)\end{array}$ & $\begin{array}{l}\leftrightarrow \text { Politicization undermines } \\
\text { textual frame (no opinion shift) }\end{array}$ \\
\hline Extreme Weather Frame & $\begin{array}{l}\text { Competing text frames } \\
\text { only }(N=219)\end{array}$ & $\begin{array}{l}\leftrightarrow \rightarrow \text { Politicization undermines } \\
\text { textual frame (no opinion shift) }\end{array}$ \\
\hline $\begin{array}{l}\text { Coastal Flooding + } \\
\text { Image (Boston) }\end{array}$ & $\begin{array}{l}\text { Competing text frames }+ \\
\text { Animated } \operatorname{Map}(N=223)\end{array}$ & $\begin{array}{l}\text { Do images in conjunctions with } \\
\text { the text overcome politicization's } \\
\text { effects? }\end{array}$ \\
\hline $\begin{array}{l}\text { Extreme Weather Frame } \\
+ \text { Image (Heat Map) }\end{array}$ & $\begin{array}{l}\text { Competing text frames }+ \\
\text { Animated Map }(N=221)\end{array}$ & $\begin{array}{l}\text { Do images in conjunctions with } \\
\text { the text overcome politicization's } \\
\text { effects? }\end{array}$ \\
\hline
\end{tabular}


Table 2: Treatment Effects - Happening, Impact, Important

\begin{tabular}{|c|c|c|c|c|c|c|}
\hline & $\begin{array}{l}\text { Happening } \\
\text { (Model 1) }\end{array}$ & $\begin{array}{c}p- \\
\text { value }\end{array}$ & $\begin{array}{c}\text { Impact } \\
\text { (Model 2) }\end{array}$ & p-value & $\begin{array}{l}\text { Important } \\
\text { (Model 3) }\end{array}$ & p-value \\
\hline Flood text & $\begin{array}{l}0.20^{*} \\
(0.12)\end{array}$ & 0.05 & $\begin{array}{l}-0.16^{*} \\
(0.10)\end{array}$ & 0.06 & $\begin{array}{c}0.06 \\
(0.10)\end{array}$ & 0.27 \\
\hline Flood text+Map & $\begin{array}{l}0.23^{* *} \\
(0.12)\end{array}$ & 0.03 & $\begin{array}{l}-0.23^{* * *} \\
(0.10)\end{array}$ & 0.01 & $\begin{array}{c}0.13^{*} \\
(0.10)\end{array}$ & 0.09 \\
\hline Flood text+Politicization & $\begin{array}{c}0.16 \\
(0.12)\end{array}$ & 0.09 & $\begin{array}{l}-0.15^{*} \\
(0.10)\end{array}$ & 0.07 & $\begin{array}{c}0.16^{*} \\
(0.10)\end{array}$ & 0.06 \\
\hline Flood+Politicization+Map & $\begin{array}{l}0.20^{* * *} \\
(0.12)\end{array}$ & 0.05 & $\begin{array}{l}-0.19^{*} \\
(0.10)\end{array}$ & 0.03 & $\begin{array}{l}0.16^{* * *} \\
(0.10)\end{array}$ & 0.05 \\
\hline Drought text & $\begin{array}{l}0.26^{* * *} \\
(0.12)\end{array}$ & 0.02 & $\begin{array}{c}-0.31^{* * * *} \\
(0.10)\end{array}$ & 0.00 & $\begin{array}{l}0.25^{\text {** }} \\
(0.10)\end{array}$ & 0.01 \\
\hline Drought text+Map & $\begin{array}{c}0.32^{* * * *} \\
(0.12)\end{array}$ & 0.00 & $\begin{array}{c}-0.37^{* * *} \\
(0.10)\end{array}$ & 0.00 & $\begin{array}{l}0.15^{*} \\
(0.10)\end{array}$ & 0.06 \\
\hline Drought text+Politicization & $\begin{array}{c}0.14 \\
(0.12)\end{array}$ & 0.13 & $\begin{array}{l}-0.22^{* * *} \\
(0.10)\end{array}$ & 0.02 & $\begin{array}{c}0.06 \\
(0.10)\end{array}$ & 0.27 \\
\hline Drought+Politicization+Map & $\begin{array}{c}0.37^{* * * *} \\
(0.12)\end{array}$ & 0.00 & $\begin{array}{l}-0.26^{* * *} \\
(0.10)\end{array}$ & 0.01 & $\begin{array}{l}0.18^{\text {*** }} \\
(0.10)\end{array}$ & 0.04 \\
\hline Republican & $\begin{array}{c}-0.99^{* * * *} \\
(0.08)\end{array}$ & 0.00 & $\begin{array}{c}0.58^{* * *} \\
(0.07)\end{array}$ & 0.00 & $\begin{array}{c}-0.62^{* * *} \\
(0.06)\end{array}$ & 0.00 \\
\hline Democrat & $\begin{array}{l}0.72^{* * *} \\
(0.07)\end{array}$ & 0.00 & $\begin{array}{c}-0.61^{* * * *} \\
(0.06)\end{array}$ & 0.00 & $\begin{array}{l}0.57^{* * * *} \\
(0.06)\end{array}$ & 0.00 \\
\hline Education Level & $\begin{array}{c}0.09^{* * *} \\
(0.03)\end{array}$ & 0.00 & $\begin{array}{c}0.01 \\
(0.03)\end{array}$ & 0.41 & $\begin{array}{l}0.05^{*} \\
(0.03)\end{array}$ & 0.05 \\
\hline Constant (Control) & $\begin{array}{c}5.29^{* * *} \\
(0.16)\end{array}$ & 0.00 & $\begin{array}{c}2.90^{* * * *} \\
(0.13) \\
\end{array}$ & 0.00 & $\begin{array}{c}3.01^{* * *} \\
(0.13)\end{array}$ & 0.00 \\
\hline$N$ & 1981 & & 1982 & & 1982 & \\
\hline$A I C$ & 6603.8 & & 5908.9 & & 5794.7 & \\
\hline$B I C$ & 6670.9 & & 5976.0 & & 5861.8 & \\
\hline
\end{tabular}

Note: Cell entries are OLS regression coefficients with standard errors in parentheses. One-tail p-values are presented adjacently. Coefficient estimates represent the average treatment effect, relative to the control group, for each treatment condition. The dependent variable in Model 1 is Happening (1-7 scale, definitely not happening to definitely happening); Model 2 is Impact (1-7 scale, extremely negative to extremely positive); Model 3 is Important (1-7 scale, extremely unimportant to extremely important).

$* * * \mathrm{p}<0.01, * * \mathrm{p}<0.05, * \mathrm{p}<0.1$ 
Table 3: Treatment Effects - Affecting Weather, Learn More, Willingness to Pay

\begin{tabular}{|c|c|c|c|c|c|c|}
\hline & $\begin{array}{l}\text { Affecting } \\
\text { Weather } \\
\text { (Model 1) }\end{array}$ & $p$-value & $\begin{array}{c}\text { Learn } \\
\text { More } \\
\text { (Model 2) }\end{array}$ & $p$-value & $\begin{array}{c}\text { Willingness } \\
\text { to Pay } \\
\text { (Model 3) }\end{array}$ & $p$-value \\
\hline Flood text & $\begin{array}{c}0.05 \\
(0.10)\end{array}$ & 0.29 & $\begin{array}{c}0.16 \\
(0.15)\end{array}$ & 0.14 & $\begin{array}{c}9.78 \\
(12.40)\end{array}$ & 0.22 \\
\hline Flood text+Map & $\begin{array}{c}0.11 \\
(0.10)\end{array}$ & 0.13 & $\begin{array}{l}0.29^{* *} \\
(0.15)\end{array}$ & 0.03 & $\begin{array}{l}18.73^{*} \\
(12.42)\end{array}$ & 0.07 \\
\hline Flood text+Politicization & $\begin{array}{l}-0.04 \\
(0.10)\end{array}$ & 0.35 & $\begin{array}{l}0.25^{* *} \\
(0.15)\end{array}$ & 0.05 & $\begin{array}{l}17.99^{*} \\
(12.44)\end{array}$ & 0.07 \\
\hline Flood+Politicization+Map & $\begin{array}{l}0.22^{* *} \\
(0.10)\end{array}$ & 0.01 & $\begin{array}{l}0.27^{* *} \\
(0.15)\end{array}$ & 0.03 & $\begin{array}{c}9.66 \\
(12.35)\end{array}$ & 0.22 \\
\hline Drought text & $\begin{array}{c}0.25^{* * *} \\
(0.10)\end{array}$ & 0.00 & $\begin{array}{c}0.39^{* * * *} \\
(0.15)\end{array}$ & 0.00 & $\begin{array}{l}30.75^{* * * *} \\
(12.37)\end{array}$ & 0.01 \\
\hline Drought text+Map & $\begin{array}{c}0.33^{* * *} \\
(0.10)\end{array}$ & 0.00 & $\begin{array}{c}0.33^{* * * *} \\
(0.15)\end{array}$ & 0.01 & $\begin{array}{l}17.46^{*} \\
(12.37)\end{array}$ & 0.08 \\
\hline Drought text+Politicization & $\begin{array}{c}0.07 \\
(0.10)\end{array}$ & 0.23 & $\begin{array}{c}0.16 \\
(0.15)\end{array}$ & 0.14 & $\begin{array}{c}0.55 \\
(12.41)\end{array}$ & 0.48 \\
\hline Drought+Politicization+Map & $\begin{array}{c}0.27^{* * *} \\
(0.10)\end{array}$ & 0.00 & $\begin{array}{c}0.17 \\
(0.15)\end{array}$ & 0.12 & $\begin{array}{c}11.70 \\
(12.40)\end{array}$ & 0.17 \\
\hline Republican & $\begin{array}{c}-0.60^{* * * *} \\
(0.06)\end{array}$ & 0.00 & $\begin{array}{c}-0.78^{* * * *} \\
(0.10)\end{array}$ & 0.00 & $\begin{array}{c}-21.33^{* * *} \\
(8.05)\end{array}$ & 0.00 \\
\hline Democrat & $\begin{array}{c}0.54^{* * * *} \\
(0.06)\end{array}$ & 0.00 & $\begin{array}{c}0.69^{* * *} \\
(0.08)\end{array}$ & 0.00 & $\begin{array}{c}54.00^{* * * *} \\
(7.13)\end{array}$ & 0.00 \\
\hline Education Level & $\begin{array}{c}0.03 \\
(0.03)\end{array}$ & 0.14 & $\begin{array}{l}0.09^{* * *} \\
(0.04)\end{array}$ & 0.01 & $\begin{array}{c}14.82^{* * * *} \\
(3.40)\end{array}$ & 0.00 \\
\hline Constant (Control) & $\begin{array}{l}3.21^{* * * *} \\
(0.12)\end{array}$ & 0.00 & $\begin{array}{c}4.18^{* * * *} \\
(0.19)\end{array}$ & 0.00 & $\begin{array}{l}37.23^{* *} \\
(15.83)\end{array}$ & 0.01 \\
\hline$N$ & 1981 & & 1977 & & 1971 & \\
\hline AIC & 5649.9 & & 7310.6 & & 24757.6 & \\
\hline$B I C$ & 5717.0 & & 7377.6 & & 24824.6 & \\
\hline
\end{tabular}

Note: Cell entries are OLS regression coefficients with standard errors in parentheses. One-tail p-values are presented adjacently. Coefficient estimates represent the average treatment effect, relative to the control group, for each treatment condition. The dependent variable in Model 1 is Affecting Weather ( $1=$ not at all; $5=$ a great deal); Model 2 is Learn More (1-7 scale, extremely uninterested to extremely interested); Model 3 is Willingness to Pay $(\$ 0-\$ 500$ range $)$. *** $\mathrm{p}<0.01, * * \mathrm{p}<0.05, * \mathrm{p}<0.1$ 
Figure 1. Images for Flooding and Temperature Increase Animation

Flooding Map

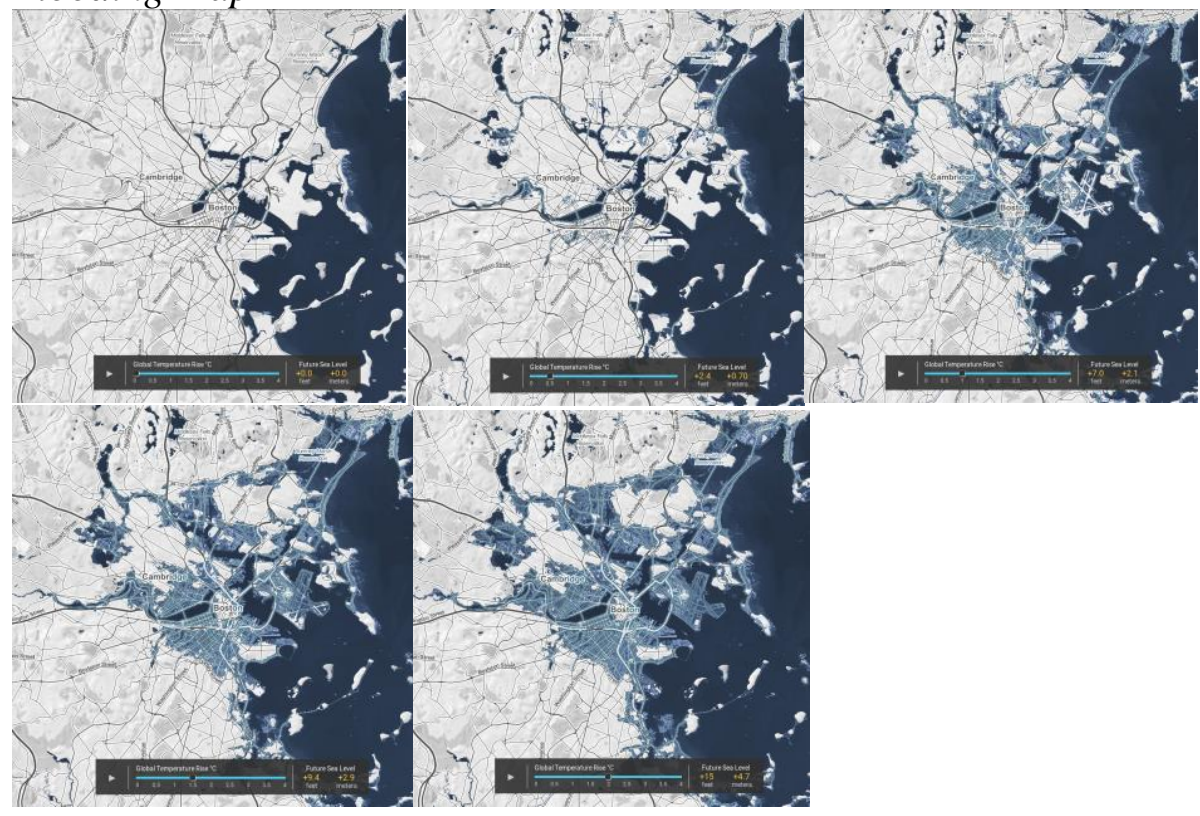

Heat Map

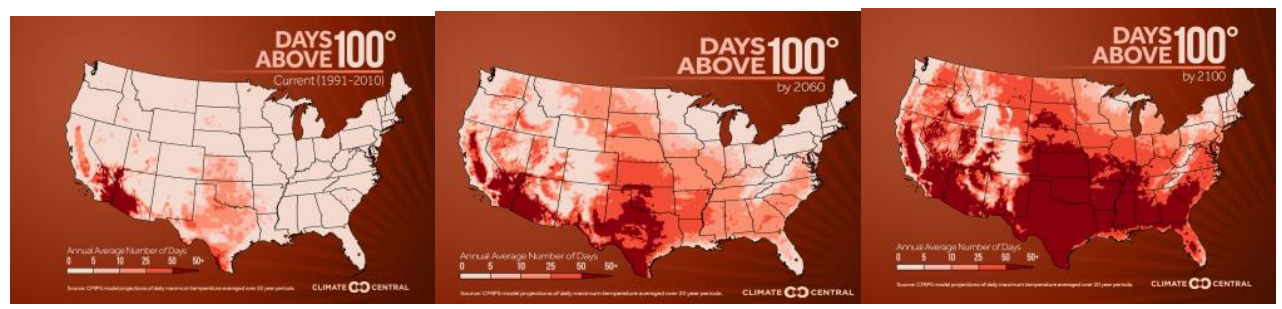

